\title{
Unfolded Protein Response Causes a Phenotypic Shift of Inflamed Glomerular Cells toward Redifferentiation through Dual Blockade of Akt and Smad Signaling Pathways
}

\author{
Hisashi Johno, ${ }^{*}$ Shotaro Nakajima, ${ }^{*}$ \\ Hironori Kato, ${ }^{*}$ Jian Yao, ${ }^{*}$ Adrienne W. Paton, ${ }^{\dagger}$ \\ James C. Paton, ${ }^{\dagger}$ Ryohei Katoh, ${ }^{\ddagger}$ Fujio Shimizu, ${ }^{\text {§q }}$ \\ and Masanori Kitamura* \begin{abstract}
Interdisciplinary Graduate School of Medicine and Engineering, University of Yamanashi, Chuo, Japan; the Research Centre for Infectious Diseases, ${ }^{\dagger}$ School of Molecular and Biomedical Science, University of Adelaide, Adelaide, Australia; the Graduate School of Medical and Dental Sciences,, Niigata University, Niigata, Japan; and the Niigata Health Care Association, " Niigata, Japan
\end{abstract} \\ From the Departments of Molecular Signaling * and Pathology,
}

During recovery from acute glomerulonephritis, cell proliferation, matrix expansion, and expression of the dedifferentiation marker $\alpha$-smooth muscle actin ( $\alpha$-SMA) subside spontaneously. However, the molecular mechanisms underlying this recovery process remain elusive. In mesangioproliferative glomerulonephritis, the unfolded protein response (UPR) is induced in activated, dedifferentiated mesangial cells. We investigated the role of the UPR in mesangial cell deactivation and redifferentiation and found that, during experimental glomerulonephritis in rats, reinforcement of the UPR significantly attenuated mesangial cell proliferation, matrix expansion, and expression of $\alpha$-SMA. Consistent with this in vivo result, induction of the UPR suppressed cell proliferation and transcriptional expression of type IV collagen (ColIV) and $\alpha$-SMA in activated mesangial cells. The UPR reduced phosphorylation of Akt in vitro and in vivo, and it was responsible for attenuation of cell proliferation. The UPR also preferentially depressed levels of total and phosphorylated Smads without affecting transcriptional levels, and it was responsible for suppression of ColIV and $\alpha$-SMA. Translational suppression via the eIF $2 \alpha$ pathway, but not proteasome-mediated protein degradation, was responsible for the down-regulation of Smads. These results suggest the novel potential of the UPR to facilitate a phenotypic shift of activated glomerular cells toward deactivation and redifferentiation. The UPR may serve as endogenous machinery that supports recovery of glomeruli from acute inflammation. (Am J Pathol 2012, 181: 1977-1990; bttp://dx.doi.org/10.1016/j.ajpath.2012.08.015)

Mesangioproliferative glomerulonephritis is the most common type of glomerular inflammation causative of chronic renal failure. In the development of mesangioproliferative glomerulonephritis, mesangial cells exhibit active proliferation, abundant production of extracellular matrix (ECM), and expression of $\alpha$-smooth muscle actin $(\alpha$-SMA), a well-known marker for dedifferentiation. For example, in anti-Thy 1 glomerulonephritis in rats, hypercellularity is observed within a few days, followed by accumulation of mesangial matrix. During this process, mesangial cells undergo dedifferentiation and express $\alpha$-SMA. ${ }^{1}$ These pathological changes are transient, however, and gradually subside. The mitogenesis of mesangial cells is attenuated, and the number of mesangial cells decreases through apoptosis. ${ }^{2}$ Expansion of the mesangial matrix is reduced by attenuation of ECM production, and activated, dedifferentiated mesangial cells regain the differentiated phenotype during the resolution phase. After a few months, the glomeruli recover from inflammation, and normal glomeruli are reconstructed. ${ }^{3}$ At this stage, mesangial cells do not proliferate actively, do not produce excessive ECM, and never express

Supported by the Ministry of Education, Culture, Sports, Science and Technology, Japan (grant-in-aid for scientific research no. 20390235 to M.K.).

Accepted for publication August 15, 2012.

Supplemental material for this article can be found at http://ajp. amjpathol.org or at $h$ ttp://dx.doi.org/10.1016/j.ajpath.2012.08.015.

Address reprint requests to Masanori Kitamura, M.D., Ph.D., Department of Molecular Signaling, Interdisciplinary Graduate School of Medicine and Engineering, University of Yamanashi, Shimokato 1110, Chuo, Yamanashi 409-3898, Japan. E-mail: masanori@yamanashi.ac.jp. 
$\alpha$-SMA. The molecular mechanisms underlying this recovery process remain unclear.

Endoplasmic reticulum (ER) stress is defined as accumulation of unfolded or misfolded proteins in the ER, which triggers an adaptive program called the unfolded protein response (UPR). Under pathological situations, ER stress is induced in the kidney and may contribute to various renal diseases. ${ }^{4}$ Previous reports showed that the UPR was induced in glomeruli of rats with passive Heymann nephritis; interestingly, ER stress preconditioning attenuated proteinuria in this experimental model. ${ }^{5,6} \mathrm{An}$ other report ${ }^{7}$ demonstrated that, in the anti-Thy 1 model of acute glomerulonephritis, the UPR was induced in inflamed glomeruli, especially in mesangial cells and podocytes; preconditioning with subtoxic doses of ER stress inducers ameliorated the pathological manifestations of this disease. The UPR may have renoprotective potential in glomerular inflammation. Suppression of NF$\kappa \mathrm{B}$, a key regulator for inflammatory processes, may be at least in part responsible for the anti-inflammatory potential of the UPR, as we have reviewed elsewhere. ${ }^{8,9}$ The question remained, however, whether and how the UPR contributes to subsidence and redifferentiation of activated glomerular cells, especially mesangial cells.

In the present study, we examined how the UPR modulates proliferation, matrix production, and differentiation of activated mesangial cells in vivo and in vitro. We investigated molecular mechanisms underlying the regulation of mesangial cell phenotype by the UPR, especially focusing on mitogenic kinases and Smad signaling. The present results suggest for the first time that the UPR has the potential to facilitate deactivation and redifferentiation of glomerular cells, which may support reconstruction of normal glomeruli during inflammation.

\section{Materials and Methods}

\section{Cells}

The rat mesangial cell line SM43 was established as described previously ${ }^{10}$; this line was used for experiments unless indicated otherwise. Primary cultures of rat mesangial cells (passages 3 to 6) were also prepared, using isolated glomeruli from kidneys of a male SpragueDawley rat, and used for experiments. Normal alveolar rat macrophage NR8383 was a gift from Dr. Seishiro Hirano (National Institute for Environmental Studies, Tsukuba, Japan). The murine macrophage-like cell line J774.1 was purchased from the American Type Culture Collection (ATCC, Manassas, VA). Cells were maintained in Dulbecco's modified Eagle's medium/Ham's F-12 (Gibco-BRL; Life Technologies, Carlsbad, CA) supplemented with 5\% to $20 \%$ fetal bovine serum. Experiments were performed in the presence of $5 \%$ fetal bovine serum.

\section{Reagents}

Tunicamycin and thapsigargin were purchased from Sigma-Aldrich Japan (Tokyo, Japan) and were used at 0.02 to $2.5 \mu \mathrm{g} / \mathrm{mL}$ for tunicamycin and 10 to $500 \mathrm{nmol} / \mathrm{L}$ for thapsigargin. Subtilase cytotoxin (SubAB) was purified by nickel-nitriloacetic acid chromatography from recombinant Escherichia coli, as described previously, ${ }^{11,12}$ and was used at 0.1 to $100 \mathrm{ng} / \mathrm{mL}$. Akti-1/2 was purchased from Calbiochem (San Diego, CA). Human transforming growth factor- $\beta 1$ (TGF- $\beta 1$ ) and recombinant human bone morphogenic protein 4 (BMP4) were purchased from R\&D Systems (Minneapolis, MN), salubrinal from Tocris Bioscience (Ellisville, MO), and MG132 from Peptide Institute (Osaka, Japan). Anti-Thy 1 mAb 1-22-3 was prepared and characterized as described previously. ${ }^{13}$ Lipopolysaccharide was purchased from Sigma-Aldrich Japan.

\section{Cell Counting and Mitogenesis Assay}

The number of viable cells and dead cells was assessed by Trypan Blue exclusion. ${ }^{14}$ Assays were performed in quadruplicate.

Cell proliferation (ie, mitogenesis) was measured using a cell proliferation enzyme-linked immunosorbent assay (ELISA) bromodeoxyuridine (BrdU) colorimetric kit (Roche Diagnostics, Tokyo, Japan). In brief, cells in 96well plates were pulse-labeled with $\mathrm{BrdU}$ for 12 hours. The cells were fixed and reacted with a peroxidase-conjugated anti-BrdU antibody for 90 minutes. After incubation with a substrate, absorbance was read at $450 \mathrm{~nm}$. Assays were performed in quadruplicate.

\section{Establishment of Stable Transfectants}

SM/AktCA cells were established by stable transfection of SM43 cells with pcDNA3-myrHA-Akt1 encoding constitutively active Akt (AktCA; provided by Dr. Kenneth Walsh, Boston University School of Medicine, Boston, MA). ${ }^{15}$ Mock-transfected cells were also established by stable transfection with pcDNA3.1 (Invitrogen; Life Technologies, Carlsbad, CA). SM/CAGA-Luc cells were established by stable transfection with $p(C A G A)_{12}$-MLP-Luc (pCAGA-luc), which introduces a luciferase gene under the control of the CAGA motifs (provided by Dr. Atsuhito Nakao, University of Yamanashi, Yamanashi, Japan). ${ }^{16}$

\section{Transient Transfection}

Using electroporation, SM43 cells were transiently transfected with poSMA-luc (provided by Dr. Raphael Nemenoff, University of Colorado, Denver, CO), ${ }^{17}$ pSRE-luc (Stratagene Japan, Tokyo, Japan), pCAGA-luc, pBRE-luc (provided by Dr. Keiji Miyazawa, University of Yamanashi), ${ }^{18}$ or ph $\beta$-actin-luc (provided by Dr. Pi-Ling Chang, University of Alabama at Birmingham, AL). ${ }^{19}$ These plasmids introduce a luciferase gene under the control of the $\alpha$-SMA gene promoter, serum response element (SRE), CAGA box, BMP responsive element (BRE), and the $\beta$-actin promoter, respectively. The cells were treated with tunicamycin or thapsigargin in the absence or presence of TGF- $\beta 1$ or BMP4 for 24 hours and then were subjected to luciferase assay. SM43 cells were also transiently transfected with $\mathrm{p} \alpha 1 \alpha 2 \mathrm{Co}$ IIV-LacZ (pCollV-lacZ) (provided by Dr. Takeshi Matsubara, Kyoto University, Kyoto, Japan) ${ }^{20}$ or pH $\beta$ Apr-1- $\beta$ gal (ph $\beta$-actinlacZ). ${ }^{21}$ These plasmids introduce a $\beta$-galactosidase 
gene under the control of an $\alpha 1 / \alpha 2$ type IV collagen gene promoter or a $\beta$-actin gene promoter, respectively. The cells were treated with ER stress inducers for 24 hours and then were subjected to 5-bromo-4-chloro-3-indolylD-galactopyranoside (X-gal) assay. All reporter assays were performed in quadruplicate.

\section{Luciferase, X-Gal, and Formazan Assays}

Activity of luciferase was evaluated using a luciferase assay system (Promega, Madison, WI) according to the manufacturer's protocol and as described previously. ${ }^{22}$

X-gal assay was performed as described previously. ${ }^{10}$ In brief, cells were fixed in $0.5 \%$ glutaraldehyde, 2 $\mathrm{mmol} / \mathrm{L} \mathrm{MgCl}_{2}$, and $1.25 \mathrm{mmol} / \mathrm{L}$ EGTA in PBS for 10 minutes and then incubated at $37^{\circ} \mathrm{C}$ in $\mathrm{X}$-gal solution containing $1 \mathrm{mg} / \mathrm{mL}$ X-gal (Sigma-Aldrich Japan), 20 $\mathrm{mmol} / \mathrm{L} \quad \mathrm{K}_{3} \mathrm{Fe}(\mathrm{CN})_{6}, 20 \mathrm{mmol} / \mathrm{L} \quad \mathrm{K}_{4} \mathrm{Fe}(\mathrm{CN})_{6} \cdot 3 \mathrm{H}_{2} \mathrm{O}, 2$ $\mathrm{mmol} / \mathrm{L} \mathrm{MgCl}_{2}, 0.01 \%$ sodium desoxycholate, and $0.02 \%$ Nonidet P-40 in PBS (pH 7.4). Activity of $\beta$-galactosidase was evaluated as described previously. ${ }^{23}$

Cell viability was assessed by formazan assay using a cell counting kit 8 (Dojindo Laboratory, Kumamoto, Japan) ${ }^{14}$ and was used for normalization of reporter assays. Assays were performed in quadruplicate.

\section{Northern Blot Analysis}

Total RNA was extracted by a single-step method, and Northern blot analysis was performed as described previously. ${ }^{24}$ CDNAs for $\alpha$-SMA, ${ }^{25}$ procollagen $\alpha 1(\mathrm{IV}),{ }^{26}$ CCAAT/enhancer-binding protein homologous protein (CHOP; provided by Dr. David Ron, University of Cambridge, Cambridge, UK), ${ }^{27}$ 78-kDa glucose-regulated protein (GRP78; provided by Dr. Kazunori Imaizumi, Hiroshima University, Hiroshima, Japan) ${ }^{28}$ activating transcription factor 4 (ATF4; provided by Dr. David Ron), Smad 1 to 3 (provided by Dr. Keiji Miyazawa, University of Yamanashi, Yamanashi, Japan), IL-1 $\beta,{ }^{29} \mathrm{IL}-6,{ }^{30}$ and monocyte chemoattractant protein 1 (MCP-1 $)^{31}$ were used to prepare radiolabeled probes. Expression of GAPDH was used as a loading control. Densitometric analysis was performed using ImageJ software version $1.44 \mathrm{p}$.

\section{Western Blot Analysis}

Western blot analysis was performed as described previously. ${ }^{32}$ Levels of phosphorylated Akt and total Akt protein were evaluated using a PhosphoPlus Akt (Ser473) antibody kit (Cell Signaling Technology, Danvers, MA). Levels of phosphorylated extracellular signal-regulated kinase (ERK) and total ERK protein were evaluated by using a PhosphoPlus p44/42 MAP kinase (Thr202/ Tyr204) antibody kit (Cell Signaling Technology). Levels of phosphorylated Smad1, Smad2, and Smad3 and their total protein levels were assessed using anti-phosphoSmad1 (Ser206) antibody, anti-Smad1 antibody, antiphospho-Smad2 (Ser465/467) antibody, anti-Smad2 antibody, anti-phospho-Smad3 (Ser423/425) antibody, and anti-Smad3 antibody (Cell Signaling Technology). Anti- phospho elF2 $\alpha$ (Ser51) antibody (Cell Signaling Technology), anti-elF2 $\alpha$ antibody (Santa Cruz Biotechnology, Santa Cruz, CA), anti-connexin43 antibody (Sigma-Aldrich Japan), and anti-GRP78 antibody (Santa Cruz Biotechnology) were also used for analysis. The level of $\beta$-actin, used as a loading control, was assessed using anti- $\beta$-actin antibody (Sigma-Aldrich Japan). Blots were visualized using the enhanced chemiluminescent system (Amersham; GE Healthcare, Little Chalfont, UK). Densitometric analysis was performed using ImageJ Software version 1.44p (NIH, Bethesda, MD).

\section{Animal Experiments}

Anti-Thy 1 glomerulonephritis was induced in adult male Sprague-Dawley rats (16 rats, 200 to $250 \mathrm{~g}$ body weight; CLEA Japan, Tokyo, Japan) by intravenous injection of mAb 1-22-3 (500 $\mu \mathrm{g} / \mathrm{rat}),{ }^{13}$ as described previously. ${ }^{10}$ After 3 days, the rats were treated with tunicamycin $(0.3$ to $2 \mathrm{mg} / \mathrm{kg}$ i.p.; $n=10$ ). For control groups, PBS was injected intraperitoneally. After 4 days (on day 7 ), kidneys were processed for tissue sectioning for histopathological analysis, immunohistochemistry, and TUNEL assay. Kidneys from untreated normal rats $(n=6)$ were also subjected to analyses. For the analysis of glomerular Akt, ERK and Smads, rats were treated with tunicamycin 3 days after injection of mAb 1-22-3. After 6 to 24 hours, kidneys were removed and processed for glomerular isolation using the conventional sieving method ${ }^{33}$ and then were subjected to Western blot analysis. The experiments were approved by the Animal Experiment Committee of the University of Yamanashi.

\section{Histopathological Analysis}

Kidneys were fixed in $4 \%$ phosphate-buffered paraformaldehyde overnight at $4^{\circ} \mathrm{C}$ and embedded in paraffin. Tissue sections were stained with PAS. Fifteen full-size glomeruli from individual kidneys were assessed for glomerular size, the number of glomerular cells, severity of glomerulosclerosis, the number of apoptotic cells, and the number of CD68-positive cells. Glomerulosclerosis was graded semiquantitatively and scored as follows: 0 , no sclerosis; 1 , segmental sclerosis $<30 \%$; 2 , segmental sclerosis $30 \%$ to $70 \%$; and 3 , segmental sclerosis $>70 \%$ to global sclerosis (see Supplemental Figure S1A at http://ajp.amjpathol.org). The mean sclerosis score was calculated for each rat, and the values were compared in different groups.

\section{Immunohistochemistry}

Immunohistochemical analysis was performed using antiPCNA antibody (1:100; Dako, Denmark), anti- $\alpha$-SMA antibody (1:100; Dako), anti-COL4A1 antibody (1:50; Acris Antibodies, Herford, Germany), and anti-CD68 antibody (1:100; AbD Serotec, Kidlington, UK). Anti-mouse and anti-rabbit, labeled polymer, horseradish peroxidase (Dako) were used as secondary antibodies. Peroxidase reactions were performed using 3,3'-diaminobenzidine tetrahydrochloride. The sections were counterstained 
with hematoxylin. Intensity of $\alpha$-SMA staining was graded quantitatively on a scale of 0 to 3 (see Supplemental Figure S1B at $h$ ttp://ajp.amjpathol.org).

\section{TUNEL Assay}

TUNEL assay was performed using a DeadEnd fluorometric TUNEL system (Promega), as described previously. ${ }^{34}$ The number of TUNEL-positive cells per glomerulus was counted, and the data were compared in different groups. A total of 60 glomeruli were evaluated for individual groups. DAPI (Sigma-Aldrich Japan) was used for nuclear staining. Kidney sections pretreated with DNase I were used as positive controls.

\section{Statistical Analysis}

Assays were performed in quadruplicate, and data are expressed as means \pm SEM. Statistical analysis was performed using the nonparametric U-test to compare data in different groups. A $P$ value of $<0.05$ was considered to indicate a statistically significant difference.

\section{Results}

\section{In Vivo Phenotypic Shift of Inflamed Mesangial Cells toward Deactivation and Redifferentiation by Induction of the UPR}

In the early phase of anti-Thy 1 glomerulonephritis, proliferation of mesangial cells occurs, with subsequent production of ECM; this is associated with dedifferentiation of mesangial cells, which is evidenced by expression of $\alpha$-SMA. To investigate whether in vivo induction of the UPR has the potential to facilitate deactivation and redifferentiation of mesangial cells, antiThy 1 glomerulonephritis was induced in rats. After 3 days (day 3 ), the rats were post-treated with or without tunicamycin. After an additional 4 days (on day 7), kidneys were removed and processed for histopathological analysis and immunohistochemistry (Figure 1A). Administration with the anti-Thy 1 antibody caused glomerulosclerosis with hypercellularity and matrix expansion (Figure 1B). This pathological change was substantially attenuated by treatment with tunicamycin. Quantitative analyses showed that increases in glomerular size, glomerular cell number, and glomerulosclerosis were significantly reduced by the post-treatment induction of the UPR (Figure 1, C-E). This reduction was associated with amelioration of type IV collagen (CollV) accumulation (Figure 1F) and suppression of glomerular mitogenesis indicated by staining for proliferating cell nuclear antigen (PCNA; Figure 1, G and $H$ ). Consistent with these results, expression of $\alpha$-SMA, which is not observed in normal glomeruli, was markedly induced in nephritic glomeruli, and was significantly repressed by the reinforcement of the UPR (Figure $1, I$ and J). Of note, in glomeruli, TUNEL-positive cells were scarcely detectable in all three groups (see Supplemental Figure S2 at http://ajp.amjpathol.org), suggesting that the decrease in glomerular cell number caused by the UPR should not be ascribed to induction of apoptosis but rather to suppression of cell proliferation. These results indicate that the UPR has the potential to facilitate deactivation and redifferentiation of mesangial cells in vivo.

\section{Inhibition of Mesangial Cell Proliferation by the UPR via Suppression of Akt}

Under serum-stimulated conditions, cultured mesangial cells exhibit a dedifferentiated phenotype that mimics activated mesangial cells in vivo (ie, active mitogenesis and proliferation, abundant production of ECM components, and expression of $\alpha$-SMA, a wellknown marker for dedifferentiation). ${ }^{35}$ To examine effects of the UPR on the activated phenotype of mesangial cells, serum-stimulated SM43 mesangial cells were exposed to subtoxic doses of the ER stress inducers tunicamycin, thapsigargin, or SubAB for 24 hours, and the number of viable cells, mitogenic activity, and cellular death were evaluated. Phase-contrast microscopy and Trypan Blue analysis showed that untreated cells proliferated actively and that the number of viable cells increased. Under induction of the UPR, however, the increase in cell number was suppressed (Figure 2, A and B). The reduction in the viable cell number was ascribed mainly to mitogenic suppression (Figure 2C), rather than to induction of cell death (Figure 2D). This result was further confirmed using rat mesangial cells in primary culture (see Supplemental Figure S3, A-C, at http://ajp.amjpathol.org).

In general, Akt and ERK play crucial roles in mitogenesis and proliferation of various cell types, including mesangial cells. ${ }^{36,37}$ To investigate molecular mechanisms involved in the antimitogenic effect of the UPR, effects of ER stress inducers on the activity of Akt and ERK were tested. Serum-stimulated cells were treated with tunicamycin, thapsigargin, or SubAB for 24 hours, and phosphorylation of Akt and ERK was evaluated. Western blot analysis showed that activated mesangial cells exhibited high levels of phosphorylated Akt, and that this effect was markedly depressed by induction of the UPR (Figure 3A). This phenomenon was also confirmed in primary culture of mesangial cells (see Supplemental Figure S3D at http://ajp.amjpathol.org). In contrast, phosphorylation of ERK observed in activated cells was unaffected by any of the ER stress inducers (Figure 3B). This finding suggested that the Akt pathway is a selective target for the antimitogenic action of ER stress. To confirm this possibility, activated cells were treated with Akti-1/2 (a selective inhibitor of Akt) and then were subjected to analyses of proliferation, mitogenesis, and cellular death. Microscopic analysis showed that the number of mesangial cells markedly decreased in the presence of Akti-1/2 (Figure 3, C and D). The reduction in cell numbers was ascribed to mitogenic suppression (Figure 3E); the contribution of cellular death was only minimal (Figure $3 \mathrm{~F}$ ).

To further confirm our conclusions, we generated SM/ AktCA cells stably expressing constitutively active Akt 
A

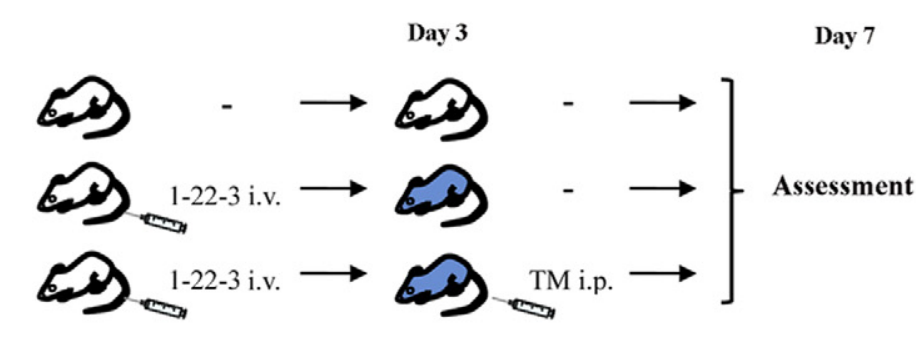

C

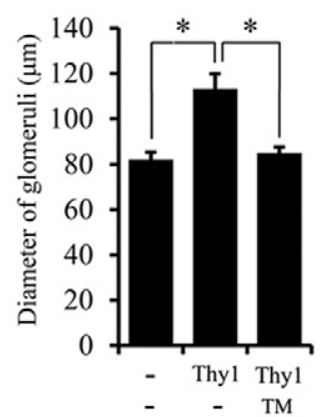

D

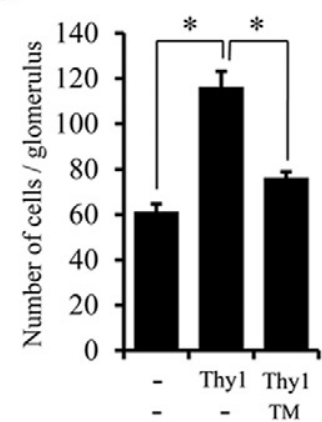

E

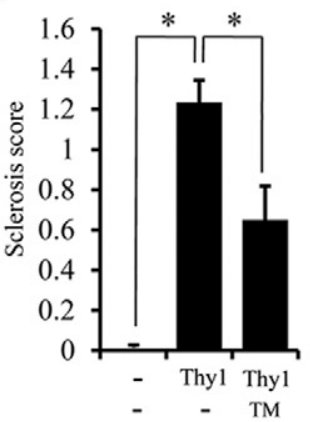

B

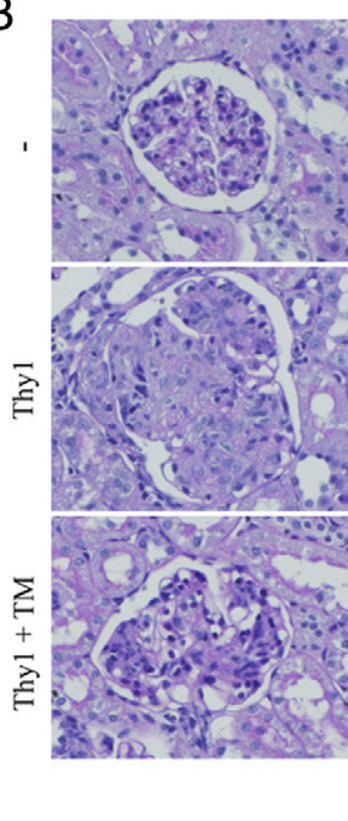

$\mathrm{F}$

Thy1

Thy $1+$ TM

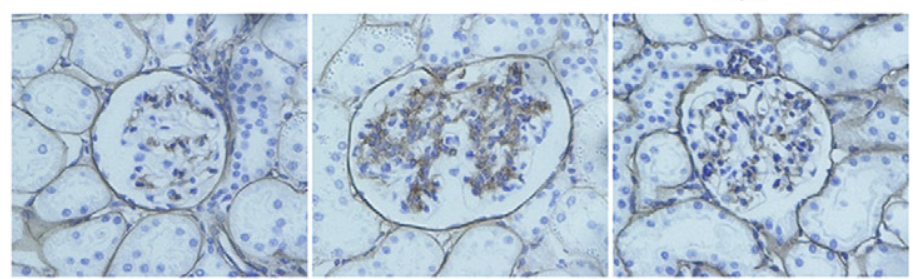

G

Thyl

Thy $1+$ TM

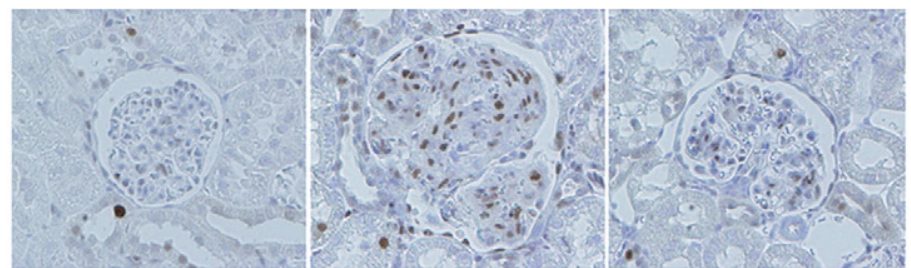

$\mathrm{H}$

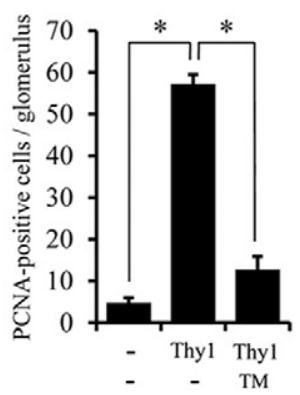

I

Thy 1

Thy $1+$ TM

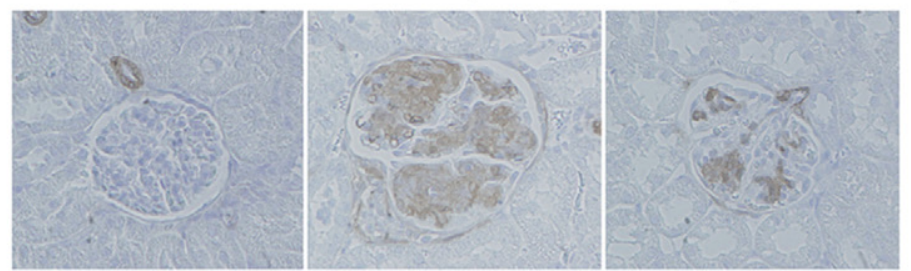

$J$

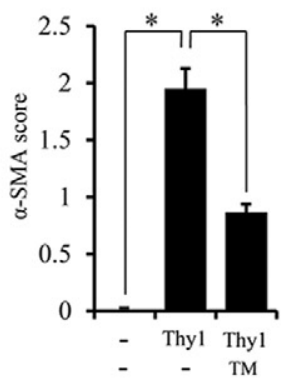

Figure 1. In vivo phenotypic shift of activated mesangial cells toward deactivation and redifferentiation by the UPR. A: Anti-Thy 1 glomerulonephritis (Thy1) was induced in rats by intravenous injection of mAb 1-22-3; after 3 days (day 3), the rats were post-treated with or without intraperitoneal injection of tunicamycin $(0.3 \mathrm{mg} / \mathrm{kg}$ ) to induce the UPR. B-J: After an additional 4 days (day 7), kidneys were subjected to histopathological analysis $(\mathbf{B}-\mathbf{E})$ and immunohistochemistry $(\mathbf{F}-\mathbf{J})$ to evaluate glomerular size $(\mathbf{C})$, the number of glomerular cells $(\mathbf{D})$, extent of glomerulosclerosis $(\mathbf{E})$, accumulation of ColIV $(\mathbf{F})$, expression of PCNA $(\mathbf{G}$ and $\mathbf{H})$, and expression of $\alpha$-SMA (I and $\mathbf{J})$. Experiments were performed in quadruplicate. Data are expressed as means \pm SEM. ${ }^{*} P<0.05$. 
A

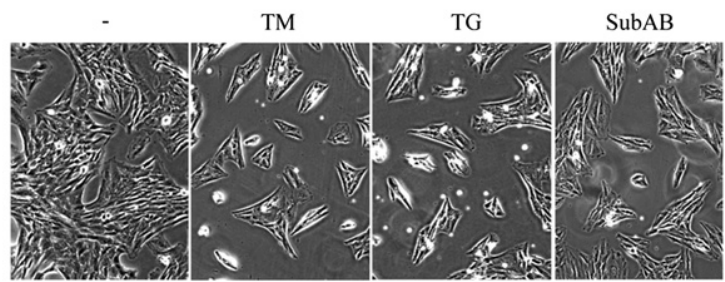

B

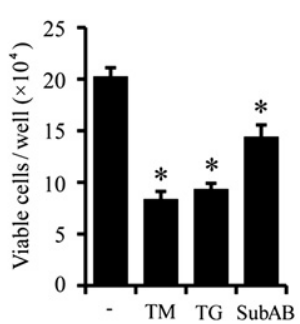

C

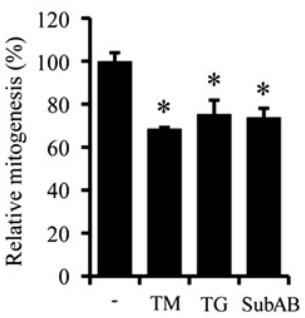

D

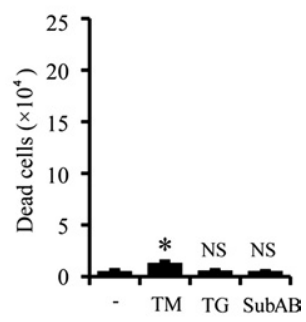

Figure 2. Inhibition of mesangial cell proliferation by the UPR. Serum-stimulated SM43 cells were exposed to tunicamycin (TM; $20 \mathrm{ng} / \mathrm{mL}$ ), thapsigargin (TG; $10 \mathrm{nmol} / \mathrm{L}$ ), or SubAB (10 ng/ $\mathrm{mL}$ ) for 24 hours and then were subjected to phase-contrast microscopy (A), cell counting (B and $\mathbf{D}$ ), and BrdU proliferation assay (C). Assays were performed in quadruplicate. Data are expressed as means \pm SEM. ${ }^{*} P<0.05$. NS, nonsignificant.
(AktCA). Enhanced phosphorylation of Akt was confirmed by Western blot analysis (Figure 3G). When mocktransfected cells were treated with thapsigargin, phosphorylation of Akt was abolished. The SM/AktCA cells, however, were relatively resistant to ER stress-induced Akt dephosphorylation. The level of $p$-Akt in thapsigargintreated SM/AktCA cells was similar to the basal activity of
Akt in activated mock transfectants (Figure 3G). Using SM/AktCA cells, an effect of the UPR on cell growth was retested. The results showed that thapsigargin reduced the number of viable cells in mock-transfected cells, and it was reversed by overexpression of AktCA (Figure 3, $\mathrm{H}$ and I). Similarly, the reduced mitogenic activity caused by the UPR was reversed by AktCA (Figure 3J). Taken
A

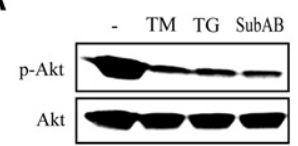

C

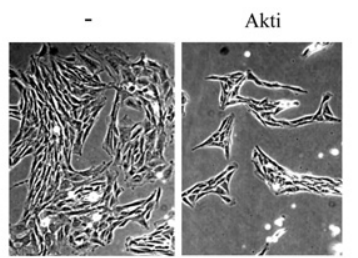

G

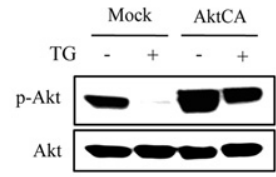

I

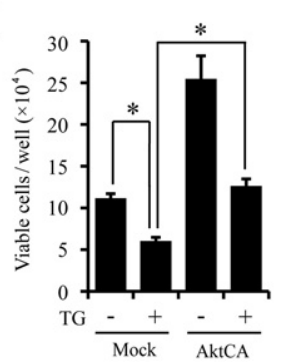

B

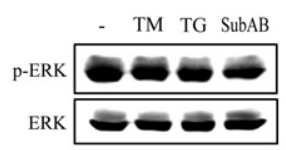

$\mathrm{E}$
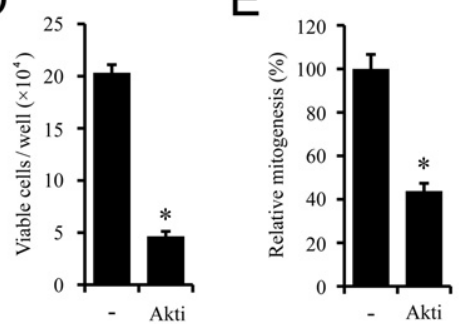

$\mathrm{F}$

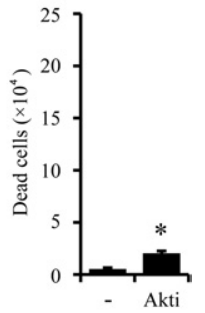

Figure 3. Selective suppression of Akt and consequent inhibition of mitogenesis by the UPR. A and B: SM43 cells activated by serum were treated with TM, TG, or SubAB for 24 hours and then subjected to Western blot analysis of phosphorylated Akt (p-Akt) (A) and phosphorylated ERK (p-ERK) (B). Total Akt protein and total ERK protein were used as loading controls. C-F: Activated cells were treated with or without Akti-1/2 (Akti; $10 \mu \mathrm{mol} / \mathrm{L}$ ) for 36 hours and then were subjected to phase-contrast microscopy $(\mathbf{C})$, cell counting (D and $\mathbf{F}$ ), and BrdU proliferation assay (E). G-J: Mock-transfected cells (Mock) or SM/AktCA cells (AktCA) were stimulated by TG for 30 hours and then subjected to Western blot analysis of p-Akt (G), microscopic analysis (H), cell counting (I), and BrdU proliferation assay $(\mathbf{J})$. Data are expressed as means \pm SEM. ${ }^{*} P<0.05$.

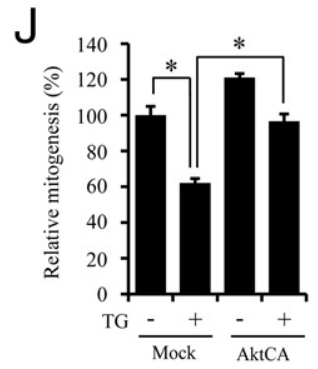




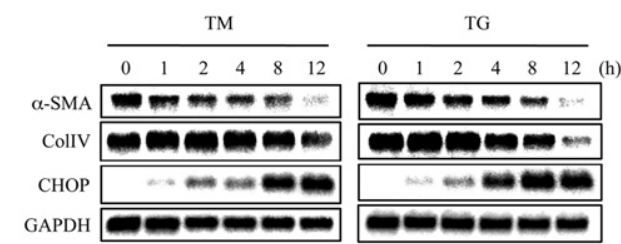

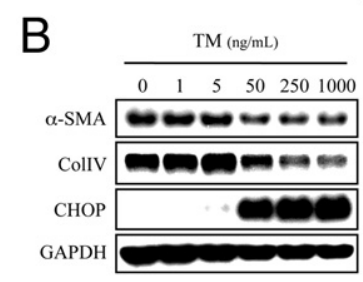
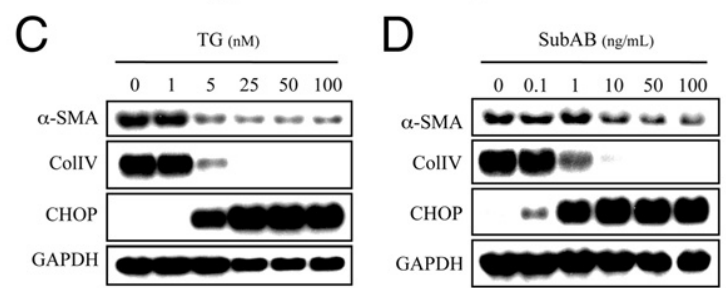

E

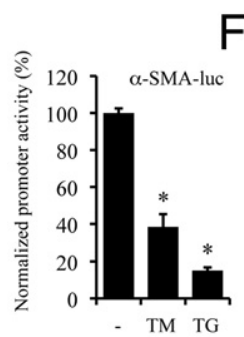

$\mathrm{F}$

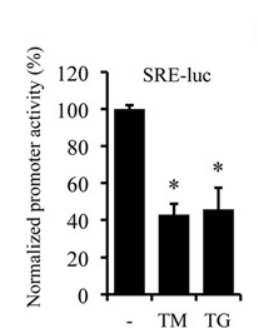

G

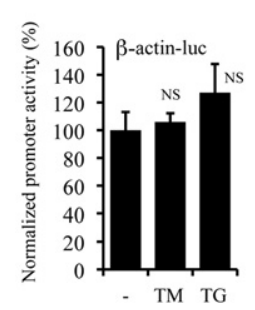

$\mathrm{H}$

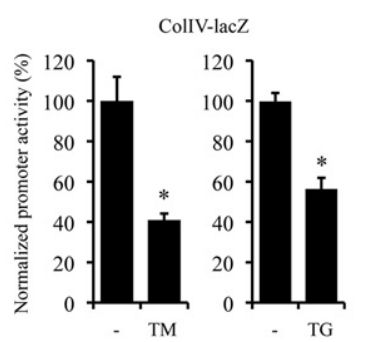

$J$
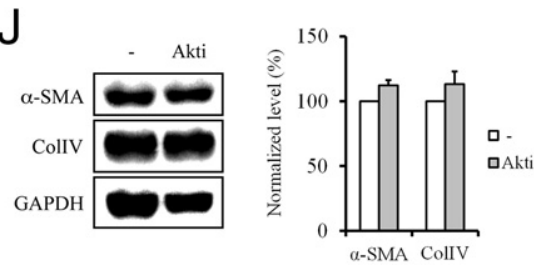

together, these results suggest that Akt is a crucial regulator of mesangial cell proliferation and that dephosphorylation of Akt is a major mechanism by which the UPR exerts its antimitogenic effect.

\section{Transcriptional Suppression of $\alpha$-SMA and CollV by the UPR via Interference with the Smad Signaling Pathways}

Activated mesangial cells exhibit production of $\alpha$-SMA and CollV abundantly. The UPR might reduce production of these proteins via translational suppression caused by eukaryotic translation initiation factor $2 \alpha(\mathrm{elF} 2 \alpha){ }^{38}$ To investigate whether and how the UPR modulates transcriptional expression of $\alpha$-SMA and CollV, activated mesangial cells were treated with tunicamycin or thapsigargin for up to 12 hours and then were subjected to Northern blot analysis. Both ER stress inducers down- regulated mRNA levels of $\alpha$-SMA and CollV, and this effect was inversely correlated with up-regulation of $\mathrm{CHOP}$, a marker of the UPR (Figure 4A). The suppressive effects of tunicamycin and thapsigargin were dose-dependent (Figure 4, B and C). Similar dose-dependent suppression was also observed for SubAB (Figure 4D). Suppression of $\alpha$-SMA and CollV mRNAs was inversely correlated with up-regulation of $\mathrm{CHOP}$. This phenomenon was also observed in primary culture of mesangial cells treated with tunicamycin and thapsigargin (see Supplemental Figure S3E at $h$ ttp://ajp.amjpathol.org).

To examine whether the depression of these mRNAs can be ascribed to transcriptional suppression, activity of the $\alpha$-SMA gene promoter and the CollV gene promoter was evaluated. Cells were transiently transfected with p $\alpha$ SMA-luc, pSRE-luc, or pCollV-lacZ and treated with ER stress inducers. Induction of the UPR significantly suppressed activity of the $\alpha$-SMA gene promoter and its 
A

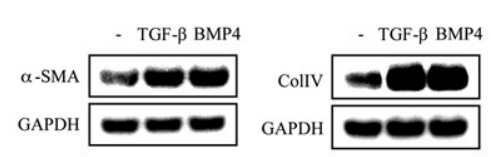

B

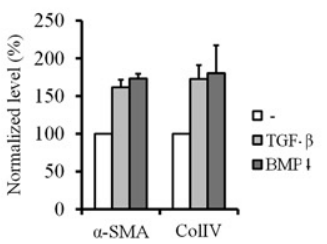

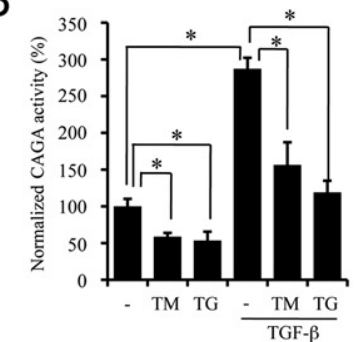

C

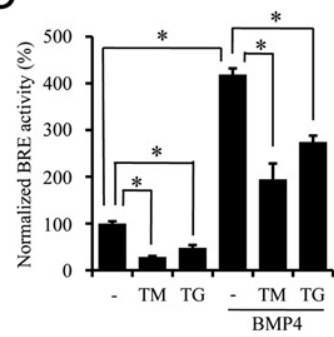

D

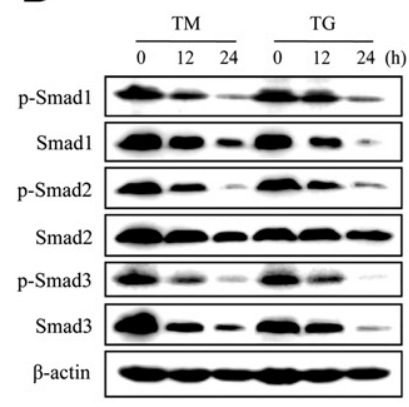

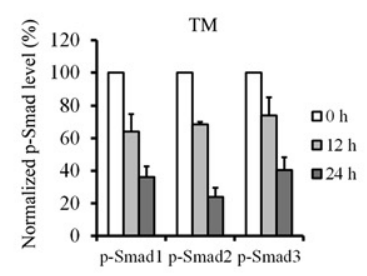

TM

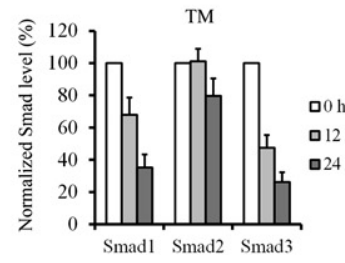

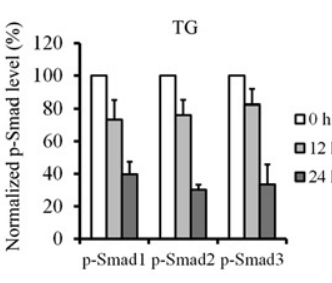

TG

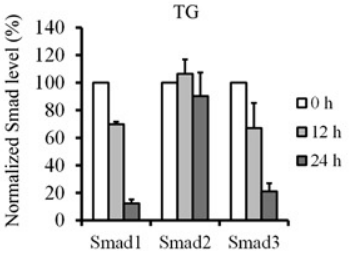

Figure 5. Suppression of Smad signaling pathways by the UPR. A: SM43 cells were treated with TGF- $\beta 1(5 \mathrm{ng} / \mathrm{mL})$ or BMP $4(50 \mathrm{ng} / \mathrm{mL})$ for 24 hours and then were subjected to Northern blot analysis of $\alpha$-SMA and ColIV. B and C: Serumstimulated SM43 cells were transiently transfected with pCAGA-luc (B) or pBRE-luc (C), stimulated by TG or TM in the absence or presence of TGF- $\beta 1$ (B) or BMP 4 (C) for 24 hours, and then subjected to luciferase assay. In each group, the value was normalized by the level of viable cells estimated by formazan assay. D: Cells were incubated with TM or TG for 0,12 , or 24 hours and then were subjected to Western blot analysis of phosphorylated Smads (p-Smad1, p-Smad2, and p-Smad3). Total protein levels of individual Smads are also shown. $\beta$-actin was used as a loading control. Levels of phosphorylated total Smads were normalized by the levels of $\beta$-actin. Data are expressed as means \pm SEM. ${ }^{*} P<0.05$.

core sequence SRE (Figure 4, E and F). This suppression was not due to a nonspecific effect of ER stress, because activity of luciferase in the cells transfected with ph $\beta$ actin-luc was not affected by treatment with tunicamycin and thapsigargin (Figure 4G). Similarly, the UPR significantly suppressed activity of the CollV gene promoter (Figure $4 \mathrm{H}$ ), and this suppression was not due to a nonspecific effect of ER stress on the $\beta$-galactosidase reporter system (Figure 4I). These results suggest that the UPR down-regulates expression of $\alpha$-SMA and CollV at a transcriptional level. Of note, neither Akt inhibition nor Akt activation altered mRNA levels of $\alpha$-SMA and CollV (Figure 4, J and $\mathrm{K}$ ).

During the process of mesangioproliferative glomerulonephritis, the TGF- $\beta$ superfamily has a key role in the expansion of mesangial matrix through facilitation of ECM production. ${ }^{39,40}$ The TGF- $\beta$ proteins may also regulate expression of $\alpha$-SMA, as well as CollV, in mesangial cells. ${ }^{41,42}$ The TGF- $\beta$ superfamily includes TGF- $\beta$ /activin and BMP. In general, TGF- $\beta$ causes phosphorylation of Smad2/3, leading to activation of its responsive elements including the CAGA box. In contrast, Smad1/5/8 are phosphorylated in response to BMP, leading to activation of BRE. ${ }^{43}$ The stimulatory effect of TGF- $\beta$ on ECM synthesis is mediated by Smad3, ${ }^{44}$ and Smad3-knockout mice exhibit limited accumulation of glomerular ECM under diabetic states. ${ }^{45}$ Activation of Smad1 by BMP may also cause mesangial matrix expansion in diabetic nephropathy. ${ }^{20}$ Based on this current knowledge, we speculated that the UPR may interfere with the TGF- $\beta$ /BMP signaling pathways. To examine this hypothesis, we first tested effects of Smad signaling on the expression of $\alpha$-SMA and CollV. Northern blot analysis revealed that TGF- $\beta 1$ and BMP4 enhanced expression of $\alpha$-SMA and CollV in mesangial cells (Figure 5A). This finding sug- gests that both Smad2/3 and Smad1 pathways have the potential to up-regulate these genes. Of note, TGF- $\beta 1$ and BMP4 did not affect phosphorylation of Akt (see Supplemental Figure S4A at http://ajp.amjpathol.org), further confirming that mitogenesis and expression of $\alpha$-SMA and ColIV are regulated independently.

To further investigate effects of the UPR on the TGF- $\beta$ / BMP signaling pathways, activated mesangial cells were transiently transfected with pCAGA-luc or pBRE-luc and exposed to ER stress inducers in the absence or presence of TGF- $\beta 1$ and BMP4, respectively. Chemiluminescent assay showed that TGF- $\beta 1$ induced activation of the CAGA box, and that this activation was significantly suppressed by tunicamycin and thapsigargin (Figure 5B). This suppressive effect was also observed in serumactivated, TGF- $\beta 1$-untreated cells. We confirmed this result using cells stably transfected with pCAGA-luc (see Supplemental Figure S5A at http://ajp.amjpathol.org). Similarly, BMP4 induced activation of the BRE, and this activation was significantly suppressed by tunicamycin and thapsigargin (Figure 5C). This suppressive effect was also observed in serum-activated, BMP4-untreated cells. These results indicate that the UPR interferes with the Smad signaling pathways.

To further confirm this conclusion and to elucidate underlying mechanisms, Western blot analysis was performed to evaluate effects of the UPR on total and phosphorylated Smad proteins. In activated mesangial cells, substantial phosphorylation of Smad1, Smad2, and Smad3 was detectable, and this phosphorylation was markedly depressed by tunicamycin and thapsigargin in a time-dependent manner (Figure 5D). Interestingly, total protein levels of Smad1 and Smad3 were also reduced to the same extent as those of phosphorylated Smads, suggesting that the decrease in the level of these phosphor- 

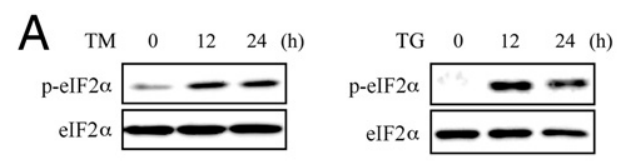

B

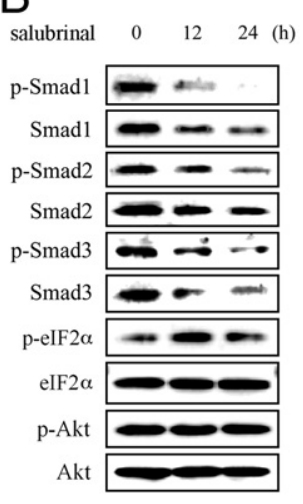

C

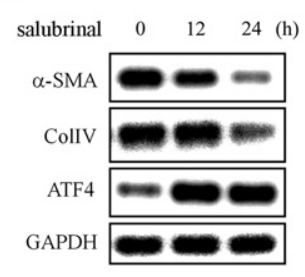

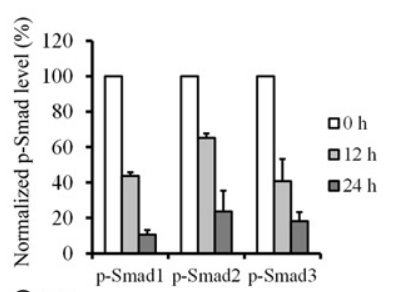
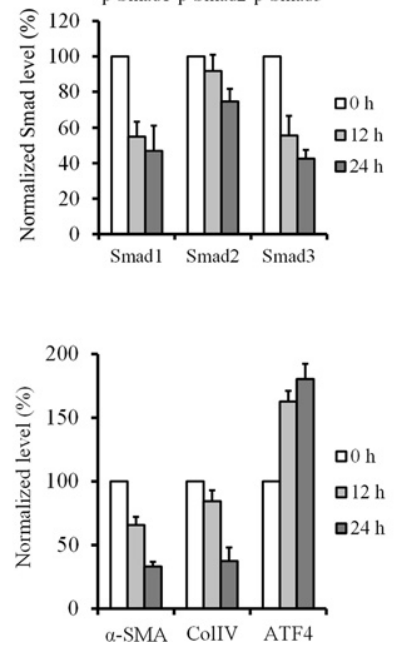
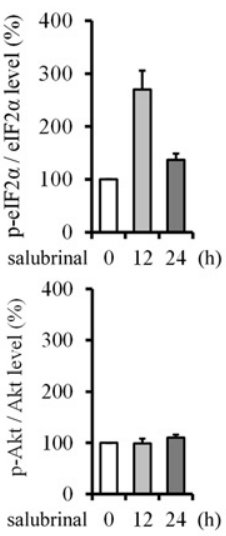

Figure 6. Suppression of Smad signaling pathways by eIF $2 \alpha$. A: SM43 cells were treated with TM or TG for 0,12 , or 24 hours and then were subjected to Western blot analysis of phosphorylated eIF $2 \alpha$ (p-eIF $2 \alpha$ ) and total eIF $2 \alpha$ protein. B and C: Activated cells were treated with 100 $\mu \mathrm{mol} / \mathrm{L}$ salubrinal for 12 to 24 hours and then were subjected to Western blot analysis (B) for phosphorylated and total Smads 1 to $3, \operatorname{EIF} 2 \alpha$, and Akt and to Northern blot analysis (C) for $\alpha$-SMA, ColIV, and ATF4, with GAPDH used as a loading control. Levels of p-eIF $2 \alpha$ and p-Akt were normalized by the levels of total eIF $2 \alpha$ and Akt. D: Cells were pretreated with TM or TG for 4 hours, further treated with MG132 ( $1 \mu \mathrm{mol} / \mathrm{L})$ for 18 hours and then were subjected to Western blot analysis of Smad1, Smad2, and Smad3. The level of connexin 43 (Cx43) was used as a positive control for MG132. An asterisk indicates a nonspecific band. Data are expressed as means \pm SEM ylated Smads can be ascribed mainly to down-regulation of total proteins. In contrast to Smad1 and Smad3, the level of total Smad2 protein was relatively preserved. These findings were further confirmed using primary culture of mesangial cells (see Supplemental Figure S3F at http://ajp.amjpathol.org). It is worth noting that mRNA levels of Smads were not reduced by treatment with tunicamycin or thapsigargin (see Supplemental Figure S5B at http://ajp.amjpathol.org).

ER stress causes general translational suppression via phosphorylation of elF $2 \alpha$. The down-regulation of Smads by the UPR may be ascribed to elF $2 \alpha$-mediated translational suppression. Indeed, treatment with tunicamycin and thapsigargin caused phosphorylation of elF2 $\alpha$ in mesangial cells (Figure 6A). To examine whether phosphorylation of elF2 $\alpha$ triggers depression of Smad proteins, we used salubrinal, a specific inhibitor of elF2 $\alpha$ dephosphorylation. Enhanced phosphorylation of elF2 $\alpha$ by salubrinal induced depression of phosphorylated Smads in a time-dependent manner (Figure 6B). Consistent with the effects of ER stress inducers (Figure 5D), total protein levels of Smads, especially Smad1 and Smad3, were also reduced by salubrinal (Figure 6B). This suppressive effect was selective of Smads, because total protein levels of elF2 $\alpha$ and Akt and the level of phosphorylated Akt were unaffected by treatment with salubrinal. Furthermore, down-regulation of phosphorylated Smads by salubrinal was correlated with suppression of $\alpha$-SMA and ColIV mRNAs, events that are downstream of the Smad signaling (Figure 6C). Of note, expression of ATF4, an event downstream of elF2 $\alpha$ activation, ${ }^{46}$ was up-regulated by treatment with salubrinal.

ER stress facilitates proteasome-mediated degradation of unfolded proteins (ie, ER-associated degradation). ${ }^{47}$ The down-regulation of Smad proteins by the UPR may be ascribed to proteasome-mediated degradation. To examine this possibility, mesangial cells were pretreated with tunicamycin or thapsigargin, treated with proteasome inhibitor MG132, and then were subjected to Western blot analysis of Smads. Connexin 43 is known to be degraded by the proteasome pathway. ${ }^{48}$ When cells were treated with ER stress inducers, the level of connexin 43 was depressed, and this effect was reversed by treatment with MG132. In contrast, depression of Smad proteins by tunicamycin and thapsigargin was not attenuated by MG132 (Figure 6D), indicating lack of involvement of the proteasome pathway for the down-regulation of Smads by the UPR.

\section{In Vivo Suppression of Glomerular Akt and Smads by the UPR}

To investigate whether in vivo induction of the UPR suppresses glomerular Akt activity and Smad signaling, we examined effects of tunicamycin (post-treatment) in antiThy 1 glomerulonephritis. At 3 days after administration with $\mathrm{mAb} 1-22-3$, animals were treated with tunicamycin to induce the UPR. After 6 to 24 hours, kidneys were removed, and isolated glomeruli were subjected to West- 
ern blot analysis of total/phosphorylated Akt and Smad proteins. Administration with tunicamycin reinforced the UPR, which was evidenced by up-regulation of GRP78 and phosphorylated elF2 $\alpha$ (Figure 7). The level of Akt phosphorylation increased in anti-Thy 1 glomerulonephritis, and this increase was attenuated by treatment with tunicamycin. This finding is consistent with the in vitro data (Figure 3A). Similarly, the levels of Smad proteins were modestly up-regulated in anti-Thy 1 glomerulonephritis, as reported previously, ${ }^{49-52}$ and Smad1 and Smad3 were down-regulated by treatment with tunicamycin. Consistent with the results in cultured mesangial cells (Figure 5D; see also Supplemental Figure S3F at $h$ ttp:// ajp.amjpathol.org), Smad2 was resistant to the suppressive effect of tunicamycin. These results suggest that induction of the UPR attenuates activity of Akt and Smad signaling in glomerular cells not only in vitro but also in vivo.

\section{Discussion}

During the process of glomerulonephritis, mesangial cells are activated and exhibit a dedifferentiated phenotype characterized by active proliferation, abundant matrix production, and abnormal expression of $\alpha$-SMA. A number of reports have described endogenous factors that may trigger mesangial cell activation and dedifferentiation. In contrast, very limited information is available regarding the machinery responsible for subsidence of activated mesangial cells. Here, we have suggested a possible role for the UPR in deactivation and redifferentiation of mesangial cells in vitro and in vivo. Under inflammatory situations, mesangial cells dedifferentiate through activation of Akt and Smad signaling. We found that the former was essential to mitogenesis, and the latter to the expression of CollV and $\alpha$-SMA. The UPR evoked by an inflammatory milieu ${ }^{7}$ may reverse this process through dual mechanisms (ie, inhibition of Akt and blockade of the Smad signaling pathways), leading to the shift of mesangial cell phenotype from the activated, dedifferentiated state to the normal, differentiated state. This hypothesis is presented schematically in Figure 8.

To our knowledge, the present study is the first to demonstrate the potential of the UPR to induce deactivation and redifferentiation of activated, dedifferentiated tissue cells under pathological conditions and also to show that Akt and Smads are preferential targets for the UPR in this process. Because Akt and Smad pathways are involved in a variety of pathological processes, our findings may open a new window on the light side of ER stress in pathological circumstances.

Previous reports have suggested that the UPR has the potential to inhibit cell proliferation. For example, Brewer and Diehl ${ }^{53}$ showed that ER stress caused induction of the protein kinase-like ER kinase (PERK)-elF2 $\alpha$ pathway and consequent translational suppression of cyclin D1, culminating in G0/G1 cell cycle arrest in NIH3T3 cells. On the other hand, Zhang et al ${ }^{54}$ reported a cyclin D1-independent mechanism in human colon cancer cells; they showed that the PERK pathway caused accumulation and activation of p53 through inhibition of its ubiquitination and degradation. The PERK-eIF2 $\alpha$ pathway may also induce expression of $\mathrm{CHOP},{ }^{55}$ which causes $\mathrm{G} 1 / \mathrm{S}$ arrest. ${ }^{56}$ Consistent with these results, the present study disclosed the antimitogenic potential of the UPR in mesangial cells. In addition to the molecular events described above, we elucidated a novel mechanism involved, namely, down-regulation of Akt phosphorylation by the UPR. Interestingly, this process was independent of the elF2 $\alpha$ pathway. The mechanisms underlying this phenomenon, however, especially UPR pathways responsible for dephosphorylation of Akt, remain unclear.

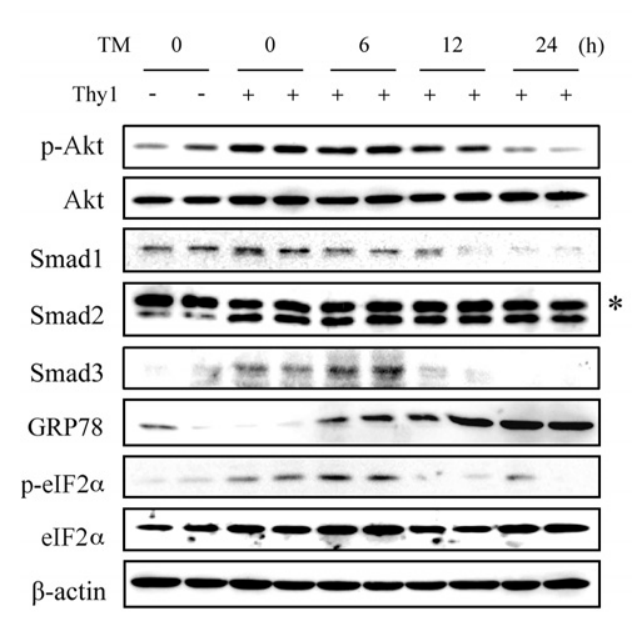

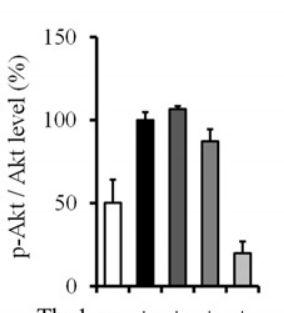

Thyl - + + + + $\begin{array}{lllllll}\text { TM } & 0 & 0 & 6 & 12 & 24 & \text { (h) }\end{array}$
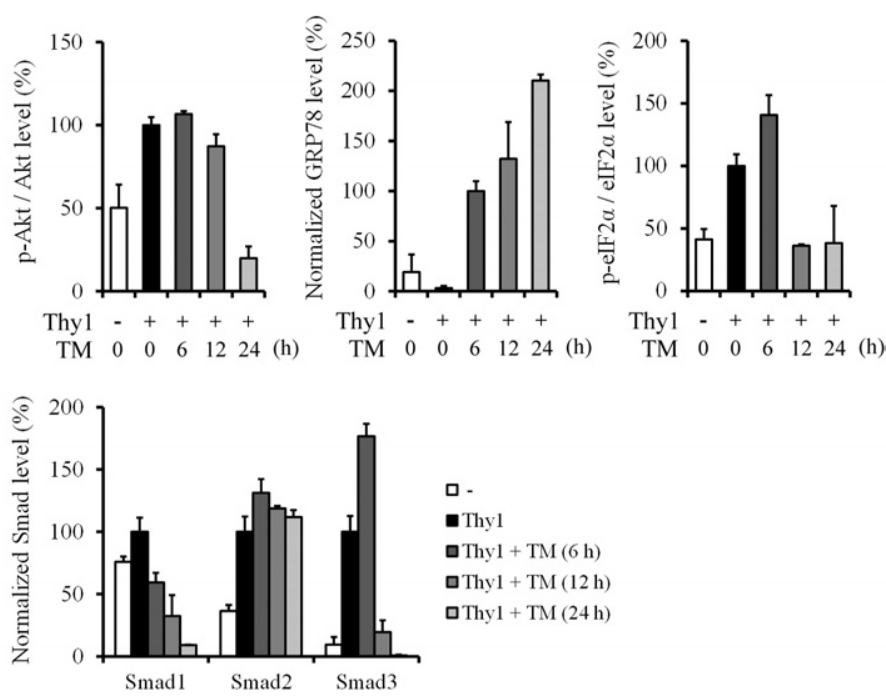

ㅁ

-Thyl

口Thyl + TM (6h)

口Thyl + TM (12 h)

口Thyl + TM (24h)

Figure 7. In vivo suppression of glomerular Akt and Smads by the UPR. Anti-Thy 1 glomerulonephritis was induced in rats by intravenous administration with mAb 1-22-3. After 3 days, animals were treated with tunicamycin to induce the UPR. After 6 to 24 hours, kidneys were removed, processed for glomerular isolation, and subjected to Western blot analysis for Akt, p-Akt, Smads 1 to 3, GRP78, p-eIF2 $\alpha$, and eIF2 $\alpha$. $\beta$-actin was used as a loading control. Levels of p-Akt and p-eIF2 $\alpha$ were normalized by their total protein levels, and levels of Smads and GRP78 were normalized by the level of $\beta$-actin. An asterisk indicates a nonspecific band. Data are expressed as means \pm SEM. 

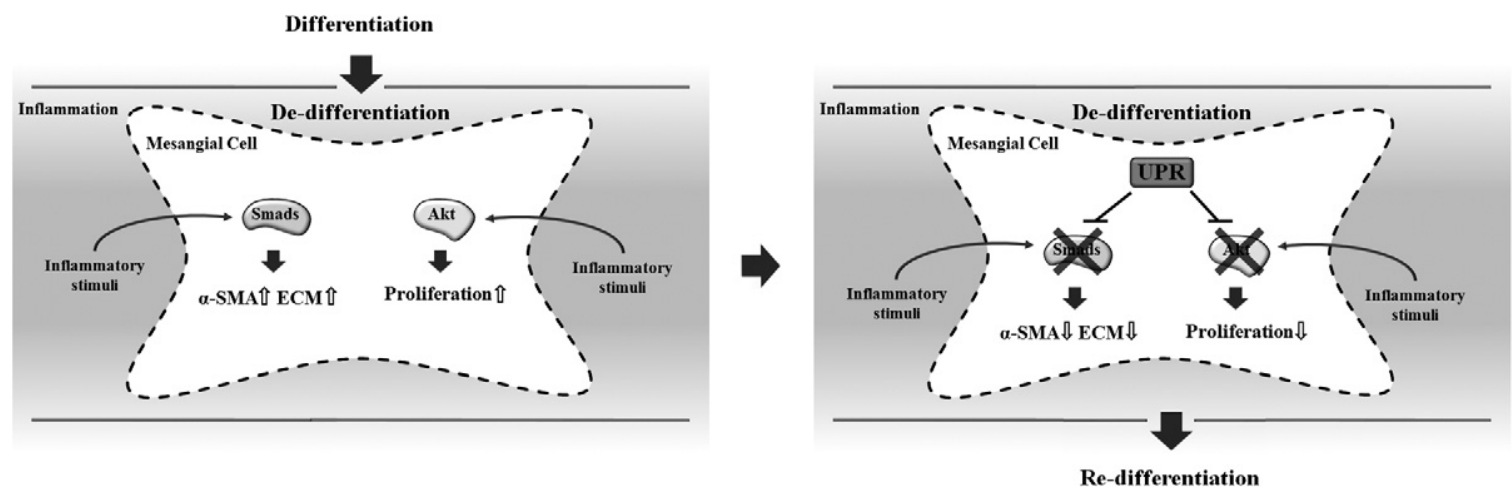

Figure 8. A model for mesangial cell deactivation and redifferentiation by the UPR. In mesangioproliferative glomerulonephritis, mesangial cells are activated by local inflammatory mediators and exhibit the dedifferentiated phenotype characterized by active proliferation, abundant ECM production (eg, ColIV), and abnormal expression of $\alpha$-SMA. Mitogenesis is caused by phosphorylation of Akt, and expression of ColIV and $\alpha$-SMA is mediated by Smads. Subsequently, the UPR is evoked in mesangial cells by the local inflammatory milieu and depresses Akt activation and Smad signaling pathways. These molecular events lead to the shift of activated, dedifferentiated mesangial cells to the normal, redifferentiated phenotype.

Nonetheless, our recent study suggested that the activating transcription factor 6 (ATF6) pathway may play an important role. ${ }^{32}$ In that study, using rat renal tubular cells and mouse embryonic fibroblasts, we demonstrated that the UPR depressed basal and TNF- $\alpha$-induced phosphorylation of Akt, mediated by induction of the ATF6 pathway and consequent activation of mammalian target of rapamycin complex 1 (mTORC1). This conclusion was deduced from the following findings. First, the UPR activated the mTORC1 pathway and caused Akt dephosphorylation. Second, inhibition of mTORC1 reversed the suppressive effect of the UPR on Akt, and activation of mTORC1 mimicked the inhibitory effect of the UPR on Akt. Third, genetic and pharmacological suppression of the ATF6 pathway, but not the PERK pathway, abrogated the UPR-triggered mTORC1 activation and dephosphorylation of $\mathrm{Akt}^{32}$ It is reasonable, therefore, to speculate that a similar mechanism may also be involved in the suppression of Akt by the UPR in glomerular cells.

In the present study, we showed that Akt, but not ERK, is a selective target for the antimitogenic action of the UPR in culture mesangial cells. Under in vivo situations, however, glomerular activity of ERK was also suppressed by the UPR. Administration with tunicamycin inhibited phosphorylation of ERK in anti-Thy 1 glomerulonephritis (see Supplemental Figure S6 at http://ajp.amjpathol.org). The reasons for the discrepancy between the in vitro and in vivo data are unclear, but the in vivo effect of tunicamycin on ERK may not involve a direct effect on mesangial cells. We found that macrophage infiltration was significantly suppressed by tunicamycin in anti-Thy 1 glomerulonephritis (see Supplemental Figure S7, A and B, at http://ajp.amjpathol.org). In this experimental model, reactive oxygen species are produced mainly by macrophages, ${ }^{57}$ and ERK is activated by reactive oxygen species in glomerular cells. ${ }^{58,59}$ The in vivo suppressive effect of tunicamycin on ERK may be caused by inhibition of macrophage infiltration and consequent reduction in local reactive oxygen species production. In addition to this effect, the UPR may also support mesangial cell deactivation and redifferentiation through direct effects on macrophages, the key players in the generation of glomerulonephritis. We found that UPR inducers attenuated expression of inflammatory cytokines and chemokines in activated macrophages (see Supplemental Figure S7, C and D, at http://ajp.amjpathol.org). These results raise the possibility that the UPR induces mesangial cell deactivation and redifferentiation not only through its direct effect but also through inactivation of macrophages.

Here, we have shown that serum-stimulated mesangial cells exhibited constitutive activation of the TGF- $\beta$ pathway. This finding is not surprising because, first, serum contains platelet-derived TGF- $\beta$ abundantly and, second, activated mesangial cells express and produce autocrine TGF- $\beta$ in vitro and in vivo. ${ }^{24,39,40}$ However, we also found constitutive activation of the BMP pathway in activated mesangial cells. The BMPs responsible for induction of this pathway are unknown. There is no evidence for production of BMPs by activated mesangial cells. A previous report showed that, like BMP, TGF- $\beta$ has the potential to induce phosphorylation of Smad1. ${ }^{60}$ The constitutive activation of the BMP pathway may be ascribed to the effect of either endogenous or exogenous TGF- $\beta$. Indeed, our preliminary data showed that, like BMP4, TGF- $\beta 1$ also induced phosphorylation of Smad1 in mesangial cells (see Supplemental Figure S4B at http://ajp.amjpathol. org).

The most important finding from the present study is that Smad proteins were selectively depressed under ER stress conditions. This depression involved the PERKelF2 $\alpha$ pathway (ie, elF2 $\alpha$-mediated translational suppression). Smad proteins, especially Smad1 and Smad3, were preferentially affected, and total protein levels of elF2 $\alpha$ and Akt were unaltered. In contrast to Smad1 and Smad3, the level of Smad2 protein was relatively preserved under activation of the elF2 $\alpha$ pathway. This difference may be ascribed to differing protein stability of the Smads. Indeed, a previous report indicated that the stability of Smad2 is higher than that of Smad3. ${ }^{61}$ Although the level of Smad2 protein was relatively constant, its phosphorylation level was markedly depressed by ER stress inducers and by salubrinal. Further investigation will be required to clarify the mechanisms involved in 
dephosphorylation of Smad2 and other Smads by the UPR.

Here, we have shown that the UPR suppressed expression of $\alpha$-SMA and CollV through down-regulation of Smad2/3 and Smad1. However, the UPR may affect expression of these proteins and their genes, especially CollV, in other ways. Hollien et $a^{62}$ reported that ER stress triggered degradation of particular mRNAs through the inositol-requiring enzyme 1 (IRE1) pathway. CollV and other ECM components are especially susceptible to this IRE1-dependent mRNA decay. Enhanced degradation of $\alpha$-SMA and CollIV mRNAs might also contribute to the down-regulation of these genes by the UPR.

In recovery from mesangioproliferative glomerulonephritis, activated mesangial cells must be subsided. The aberrant proliferation and matrix production must be attenuated, and the cells must undergo redifferentiation. The present findings suggest a possibility that the UPR contributes to this recovery process via dual suppression of both the Akt and the TGF- $\beta /$ BMP pathways. It is worth noting that the TGF- $\beta$ pathway and the phosphatidylinositol 3-kinase/Akt pathway play crucial roles in the progression of glomerulonephritis. ${ }^{63-65}$ In addition, during recovery from glomerulonephritis, increased mesangial cells are deleted through apoptosis. ${ }^{66}$ ER stress is known to induce apoptosis through induction of $\mathrm{CHOP}$, activation of caspase-12, and phosphorylation of C-Jun N-terminal kinase. ${ }^{67}$ ER stress could also contribute to the recovery of inflamed glomeruli via coordinated regulation of apoptotic cell death.

In the present study, we showed that the UPR triggered by ER stress attenuates activation and dedifferentiation of mesangial cells. This is in contrast to other cellular stresses, which usually cause mesangial cell activation and dedifferentiation. For example, hypoxic stress induces mesangial cell proliferation and overproduction of ECM, including CollV, fibronectin, and laminin. ${ }^{68,69}$ Other studies also showed that oxidative stress is involved in activation of ERK and Akt, cell proliferation, and ECM production in mesangial cells in vitro and in vivo. ${ }^{59,70}$ Metabolic stress (eg, high glucose concentrations) may also cause overproduction of ECM. ${ }^{71}$ Mesangial cells in vivo are exposed to pulsatile capillary pressure, and increased mechanical stress leads to accumulation of glomerular ECM. Using cultured mesangial cells, Yasuda et $\mathrm{al}^{72}$ provided evidence that mechanical stress increases expression of ECM components, including collagens, fibronectin, and laminin, accompanied by induction of TGF- $\beta 1$. Another study showed that mechanical stress enhanced mesangial cell proliferation, with activation of ERK and p38 mitogen-activated protein (MAP) kinase. ${ }^{73}$ Based on these previous findings, our present results disclose a unique aspect of ER stress that is distinct from other stress responses.

Previous reports by other investigators emphasized a pathogenic role of ER stress in renal injury. Inagi et $\mathrm{al}^{7}$ showed that preconditioning with ER stress ameliorated the severity of manifestations in anti-Thy 1 glomerulonephritis. They concluded that induction of modest ER stress before the insult allows glomerular cells to be resistant to prolonged or excessive ER stress during inflam- mation. In this context, ER stress is considered to be pathogenic. Our present findings, however, show that, even after the insult, induction of the UPR facilitated an in vivo phenotypic shift of mesangial cells from activated, dedifferentiated feature to the differentiated state. Our results indicate that, in addition to its dark side, ER stress may also have a light side that copes with inflammatory processes, as we have previously reviewed. . $^{4,8,9}$ We propose a possibility that ER stress-triggered UPR is not only a blackguard (so to speak), but also a safeguard in the pathogenesis of glomerulonephritis.

\section{Acknowledgments}

We thank Drs. Kenneth Walsh (Boston University School of Medicine), Atsuhito Nakao (University of Yamanashi), Raphael Nemenoff (University of Colorado), Keiji Miyazawa (University of Yamanashi), Pi-Ling Chang (University of Alabama at Birmingham), Takeshi Matsubara (Kyoto University), Kazunori Imaizumi (Hiroshima University), and David Ron (University of Cambridge) for providing us with expression plasmids, Mikiko Yoda (University of Yamanashi) for technical assistance, and Drs. Keiji Miyazawa and Atsuhito Nakao for helpful discussion.

\section{References}

1. Hugo C, Hugo C, Pichler R, Gordon K, Schmidt R, Amieva M, Couser WG, Furthmayr $\mathrm{H}$, Johnson RJ: The cytoskeletal linking proteins, moesin and radixin, are upregulated by platelet-derived growth factor, but not basic fibroblast growth factor in experimental mesangial proliferative glomerulonephritis. J Clin Invest 1996, 97:2499-2508

2. Savill J: Apoptosis: a mechanism for regulation of the cell complement of inflamed glomeruli. Kidney Int 1992, 41:607-612

3. Bagchus WM, Hoedemaeker PJ, Rozing J, Bakker WW: Glomerulonephritis induced by monoclonal anti-Thy 1.1 antibodies. A sequential histological and ultrastructural study in the rat. Lab Invest 1986, 55:680-687

4. Kitamura M: Endoplasmic reticulum stress and unfolded protein response in renal pathophysiology: Janus faces. Am J Physiol Renal Physiol 2008, 295:F323-F334

5. Cybulsky AV, Takano T, Papillon J, Khadir A, Liu J, Peng H: Complement C5b-9 membrane attack complex increases expression of endoplasmic reticulum stress proteins in glomerular epithelial cells. J Biol Chem 2002, 277:41342-41351

6. Cybulsky AV, Takano T, Papillon J, Bijian K: Role of the endoplasmic reticulum unfolded protein response in glomerular epithelial cell injury. J Biol Chem 2005, 280:24396-24403

7. Inagi R, Kumagai T, Nishi H, Kawakami T, Miyata T, Fujita T, Nangaku $M$ : Preconditioning with endoplasmic reticulum stress ameliorates mesangioproliferative glomerulonephritis. J Am Soc Nephrol 2008, 19:915-922

8. Kitamura M: Endoplasmic reticulum stress in glomerulonephritis: the bad guy turns good? J Am Soc Nephrol 2009, 20:1871-1873

9. Kitamura M: Biphasic, bidirectional regulation of NF-kappaB by endoplasmic reticulum stress. Antioxid Redox Signal 2009, 11:23532364

10. Kitamura M, Taylor S, Unwin R, Burton S, Shimizu F, Fine LG: Gene transfer into the rat renal glomerulus via a mesangial cell vector: site-specific delivery, in situ amplification, and sustained expression of an exogenous gene in vivo. J Clin Invest 1994, 94:497-505

11. Paton AW, Beddoe T, Thorpe CM, Whisstock JC, Wilce MC, Rossjohn J, Talbot UM, Paton JC: AB5 subtilase cytotoxin inactivates the endoplasmic reticulum chaperone BiP. Nature 2006, 443:548-552

12. Wang $H$, Paton JC, Paton AW: Pathologic changes in mice induced by subtilase cytotoxin, a potent new Escherichia coli AB5 toxin that targets the endoplasmic reticulum. J Infect Dis 2007, 196:1093-1101 
13. Kawachi H, Orikasa M, Matsui K, Iwanaga T, Toyabe S, Oite $T$, Shimizu F: Epitope-specific induction of mesangial lesions with proteinuria by a MoAb against mesangial cell surface antigen. Clin Exp Immunol 1992, 88:399-404

14. Johno H, Takahashi S, Kitamura M: Influences of acidic conditions on formazan assay: a cautionary note. Appl Biochem Biotechnol 2010, 162:1529-1535

15. Fujio Y, Guo K, Mano T, Mitsuuchi Y, Testa JR, Walsh K: Cell cycle withdrawal promotes myogenic induction of Akt, a positive modulator of myocyte survival. Mol Cell Biol 1999, 19:5073-5082

16. Dennler S, Itoh S, Vivien D, ten Dijke P, Huet S, Gauthier JM: Direct binding of Smad3 and Smad4 to critical TGF beta-inducible elements in the promoter of human plasminogen activator inhibitor-type $1 \mathrm{gene}$ EMBO J 1998, 17:3091-3100

17. Garat C, Van Putten V, Refaat ZA, Dessev C, Han SY, Nemenoff RA: Induction of smooth muscle alpha-actin in vascular smooth muscle cells by arginine vasopressin is mediated by c-Jun amino-termina kinases and p38 mitogen-activated protein kinase. J Biol Chem 2000 275:22537-22543

18. Korchynskyi $\mathrm{O}$, ten Dijke $\mathrm{P}$ : Identification and functional characterization of distinct critically important bone morphogenetic proteinspecific response elements in the Id1 promoter. J Biol Chem 2002 277:4883-4891

19. Feng $G$, Hicks $P$, Chang PL: Differential expression of mammalian or viral promoter-driven gene in adherent versus suspension cells. In Vitro Cell Dev Biol Anim 2003, 39:420-423

20. Matsubara $T$, Abe $H$, Arai H, Nagai K, Mima A, Kanamori H, Sumi E, Takahashi T, Matsuura M, lehara N, Fukatsu A, Kita T, Doi T: Expression of Smad1 is directly associated with mesangial matrix expansion in rat diabetic nephropathy. Lab Invest 2006, 86:357-368

21. Klünder I, Hülser DF: beta-Galactosidase activity in transfected Ltkcells is differentially regulated in monolayer and in spheroid cultures. Exp Cell Res 1993, 207:155-162

22. Hiramatsu N, Kasai A, Hayakawa K, Yao J, Kitamura M: Real-time detection and continuous monitoring of ER stress in vitro and in vivo by ES-TRAP: evidence for systemic, transient ER stress during endotoxemia. Nucleic Acids Res 2006, 34:e93

23. Ishikawa Y, Kitamura M: Unexpected suppression of alpha-smooth muscle actin, the activation marker of mesangial cells, by pp60v-src tyrosine kinase. Biochem Biophys Res Commun 1998, 244:806-811

24. Kitamura M: TGF-beta1 as an endogenous defender against macrophage-triggered stromelysin gene expression in the glomerulus. J Immunol 1998, 160:5163-5168

25. McHugh KM, Lessard JL: The nucleotide sequence of a rat vascular smooth muscle alpha-actin cDNA. Nucleic Acids Res 1988, 16:4167

26. Oberbäumer I, Laurent M, Schwarz U, Sakurai Y, Yamada Y, Vogeli G, Voss T, Siebold B, Glanville RW, Kühn K: Amino acid sequence of the non-collagenous globular domain (NC1) of the alpha1(IV) chain of basement membrane collagen as derived from complementary DNA. Eur J Biochem 1985, 147:217-224

27. Wang $X Z$, Harding HP, Zhang $Y$, Jolicoeur EM, Kuroda M, Ron D: Cloning of mammalian Ire1 reveals diversity in the ER stress responses. EMBO J 1998, 17:5708-5717

28. Katayama T, Imaizumi K, Honda A, Yoneda T, Kudo T, Takeda M Mori K, Rozmahel R, Fraser P, George-Hyslop PS, Tohyama M: Disturbed activation of endoplasmic reticulum stress transducers by familial Alzheimer's disease-linked presenilin-1 mutations. J Biol Chem 2001, 276:43446-43454

29. Gray PW, Glaister D, Chen E, Goeddel DV, Pennica D: Two interleukin 1 genes in the mouse: cloning and expression of the cDNA for murine interleukin 1beta. J Immunol 1986, 137:3644-3648

30. Van Snick J, Cayphas S, Szikora JP, Renauld JC, Van Roost E, Boon T, Simpson RJ: cDNA cloning of murine interleukin-HP1: homology with human interleukin-6. Eur J Immunol 1988, 18:193-197

31. Rollins BJ, Morrison ED, Stiles CD: Cloning and expression of JE, a gene inducible by platelet-derived growth factor and whose product has cytokine-like properties. Proc Natl Acad Sci USA 1988, 85:37383742

32. Nakajima S, Hiramatsu N, Hayakawa K, Saito Y, Kato H, Huang T, Yao J, Paton AW, Paton JC, Kitamura M: Selective abrogation of BiP/ GRP78 blunts activation of NF-kappaB through the ATF6 branch of the UPR: involvement of C/EBPbeta and mTOR-dependent dephosphorylation of Akt. Mol Cell Biol 2011, 31:1710-1718
33. Ishikawa $Y$, Konta T, Kitamura M: Spontaneous shift in the transcriptional profile of explanted glomeruli via activation of the MAP kinase family. Am J Physiol Renal Physiol 2000, 279:F954-F959

34. Yokouchi M, Hiramatsu N, Hayakawa K, Kasai A, Takano Y, Yao J, Kitamura M: Atypical, bidirectional regulation of cadmium-induced apoptosis via distinct signaling of unfolded protein response. Cell Death Differ 2007, 14:1467-1474

35. Kitamura M, Mitarai T, Nagasawa R, Maruyama N: Differentiated phenotype of glomerular mesangial cells in nodular culture. Am J Physiol 1996, 270:F614-F622

36. Choudhury GG: Akt serine threonine kinase regulates platelet-derived growth factor-induced DNA synthesis in glomerular mesangial cells: regulation of $\mathrm{c}$-fos and p27(kip1) gene expression [Erratum appeared in J Biol Chem 2002, 277:870]. J Biol Chem 2001, 276: 35636-35643

37. Schramek H, Sorokin A, Watson RD, Dunn MJ: Differential long-term regulation of MEK and of $\mathrm{p} 42 \mathrm{MAPK}$ in rat glomerular mesangial cells. Am J Physiol 1996, 270:C40-C48

38. Harding HP, Zhang $Y$, Ron D: Protein translation and folding are coupled by an endoplasmic-reticulum-resident kinase [Erratum appeared in Nature 1999, 398:90]. Nature 1999, 397:271-274

39. Border WA, Okuda S, Languino LR, Sporn MB, Ruoslahti E: Suppression of experimental glomerulonephritis by antiserum against transforming growth factor beta1. Nature 1990, 346:371-374

40. Okuda S, Languino LR, Ruoslahti E, Border WA: Elevated expression of transforming growth factor-beta and proteoglycan production in experimental glomerulonephritis. Possible role in expansion of the mesangial extracellular matrix [Erratum appeared in $\mathrm{J}$ Clin Invest 1990, 86:2175]. J Clin Invest 1990, 86:453-462

41. Hänsch GM, Wagner C, Bürger A, Dong W, Staehler G, Stoeck M: Matrix protein synthesis by glomerular mesangial cells in culture: effects of transforming growth factor-beta (TGF-beta) and plateletderived growth factor (PDGF) on fibronectin and collagen type IV mRNA. J Cell Physiol 1995, 163:451-457

42. Stephenson LA, Haney LB, Hussaini IM, Karns LR, Glass WF 2nd: Regulation of smooth muscle alpha-actin expression and hypertrophy in cultured mesangial cells. Kidney Int 1998, 54:1175-1187

43. Moustakas A, Heldin $\mathrm{CH}$ : The regulation of TGF-beta signal transduction. Development 2009, 136:3699-3714

44. Flanders KC: Smad3 as a mediator of the fibrotic response. Int J Exp Pathol 2004, 85:47-64

45. Wang A, Ziyadeh FN, Lee EY, Pyagay PE, Sung SH, Sheardown SA, Laping NJ, Chen S: Interference with TGF-beta signaling by Smad3knockout in mice limits diabetic glomerulosclerosis without affecting albuminuria. Am J Physiol Renal Physiol 2007, 293:F1657-F1665

46. Kitamura M, Kato H, Saito $Y$, Nakajima S, Takahashi S, Johno H, Gu L, Katoh R: Aberrant, differential and bidirectional regulation of the unfolded protein response towards cell survival by 3 '-deoxyadenosine. Cell Death Differ 2011, 18:1876-1888

47. Friedlander R, Jarosch E, Urban J, Volkwein C, Sommer T: A regulatory link between ER-associated protein degradation and the unfoldedprotein response. Nat Cell Biol 2000, 2:379-384

48. Huang T, Zhu Y, Fang X, Chi Y, Kitamura M, Yao J: Gap junctions sensitize cancer cells to proteasome inhibitor MG132-induced apoptosis. Cancer Sci 2010, 101:713-721

49. Chiang CK, Sheu ML, Hung KY, Wu KD, Liu SH: Honokiol, a small molecular weight natural product, alleviates experimental mesangial proliferative glomerulonephritis. Kidney Int 2006, 70:682-689

50. Takahashi T, Abe $H$, Arai $H$, Matsubara T, Nagai K, Matsuura M, lehara N, Yokode M, Nishikawa S, Kita T, Doi T: Activation of STAT3/ Smad1 is a key signaling pathway for progression to glomerulosclerosis in experimental glomerulonephritis. J Biol Chem 2005, 280: 7100-7106

51. Ostendorf T, Kunter U, van Roeyen C, Dooley S, Janjic N, Ruckman $\mathrm{J}$, Eitner F, Floege J: The effects of platelet-derived growth factor antagonism in experimental glomerulonephritis are independent of the transforming growth factor-beta system. J Am Soc Nephrol 2002 , 13:658-667

52. Uchida K, Nitta K, Kobayashi H, Kawachi H, Shimizu F, Yumura W, Nihei $\mathrm{H}$ : Localization of Smad6 and Smad7 in the rat kidney and their regulated expression in the anti-Thy-1 nephritis. Mol Cell Biol Res Commun 2000, 4:98-105 
53. Brewer JW, DiehI JA: PERK mediates cell-cycle exit during the mammalian unfolded protein response. Proc Natl Acad Sci USA 2000 97:12625-12630

54. Zhang F, Hamanaka RB, Bobrovnikova-Marjon E, Gordan JD, Dai MS, Lu H, Simon MC, Diehl JA: Ribosomal stress couples the unfolded protein response to p53-dependent cell cycle arrest. J Biol Chem 2006, 281:30036-30045

55. Harding HP, Novoa I, Zhang Y, Zeng H, Wek R, Schapira M, Ron D: Regulated translation initiation controls stress-induced gene expression in mammalian cells. Mol Cell 2000, 6:1099-1108

56. Barone MV, Crozat A, Tabaee A, Philipson L, Ron D: CHOP (GADD153) and its oncogenic variant. TLS-CHOP, have opposing effects on the induction of G1/S arrest. Genes Dev 1994, 8:453-464

57. Nakamura K, Oka M, Shirai M, Igarashi Y, Kojima K, Kaneko O, Hamada N, Mera J, Masaoka H, Nagase M: Source of reactive oxygen species in anti-Thy1 nephritis. Ren Fail 1998, 20:399-405

58. Greene EL, Houghton O, Collinsworth G, Garnovskaya MN, Nagai T, Sajjad T, Bheemanathini V, Grewal JS, Paul RV, Raymond JR: 5-HT2A receptors stimulate mitogen-activated protein kinase via $\mathrm{H} 2 \mathrm{O} 2$ generation in rat renal mesangial cells. Am J Physiol Renal Physiol 2000 , 278:F650-F658

59. Budisavljevic MN, Hodge L, Barber K, Fulmer JR, Durazo-Arvizu RA, Self SE, Kuhlmann M, Raymond JR, Greene EL: Oxidative stress in the pathogenesis of experimental mesangial proliferative glomerulonephritis. Am J Physiol Renal Physiol 2003, 285:F1138-F1148

60. Yue J, Frey RS, Mulder KM: Cross-talk between the Smad1 and Ras/MEK signaling pathways for TGFbeta. Oncogene 1999, 18:20332037

61. Guo X, Ramirez A, Waddell DS, Li Z, Liu X, Wang XF: Axin and GSK3-beta control Smad3 protein stability and modulate TGF-beta signaling. Genes Dev 2008, 22:106-120

62. Hollien J, Lin JH, Li H, Stevens N, Walter P, Weissman JS: Regulated Ire1-dependent decay of messenger RNAs in mammalian cells. J Cell Biol 2009, 186:323-331

63. Cox SN, Sallustio F, Serino G, Pontrelli P, Verrienti R, Pesce F, Torres DD, Ancona N, Stifanelli P, Zaza G, Schena FP: Altered modulation of
WNT-beta-catenin and PI3K/Akt pathways in IgA nephropathy. Kidney Int 2010, 78:396-407

64. Barber DF, Bartolomé A, Hernandez C, Flores JM, Redondo C, Fernandez-Arias C, Camps M, Rückle T, Schwarz MK, Rodríguez S, Martinez-A C, Balomenos D, Rommel C, Carrera AC: PI3K-gamma inhibition blocks glomerulonephritis and extends lifespan in a mouse model of systemic lupus. Nat Med 2005, 11:933-935

65. Border WA, Ruoslahti E: Transforming growth factor-beta 1 induces extracellular matrix formation in glomerulonephritis. Cell Differ Dev 1990, 32:425-431

66. Baker AJ, Mooney A, Hughes J, Lombardi D, Johnson RJ, Savill J: Mesangial cell apoptosis: the major mechanism for resolution of glomerular hypercellularity in experimental mesangial proliferative nephritis. J Clin Invest 1994, 94:2105-2016

67. Kim R, Emi M, Tanabe K, Murakami S: Role of the unfolded protein response in cell death. Apoptosis 2006, 11:5-13

68. Sahai A, Mei C, Pattison TA, Tannen RL: Chronic hypoxia induces proliferation of cultured mesangial cells: role of calcium and protein kinase C. Am J Physiol 1997, 273:F954-F960

69. Sahai A, Mei C, Schrier RW, Tannen RL: Mechanisms of chronic hypoxia-induced renal cell growth. Kidney Int 1999, 56:1277-1281

70. Dentelli P, Rosso A, Zeoli A, Gambino R, Pegoraro L, Pagano G, Falcioni R, Brizzi MF: Oxidative stress-mediated mesangial cell proliferation requires $\mathrm{RAC}-1 /$ reactive oxygen species production and beta4 integrin expression. J Biol Chem 2007, 282:2610126110

71. Catherwood MA, Powell LA, Anderson P, McMaster D, Sharpe PC, Trimble ER: Glucose-induced oxidative stress in mesangial cells. Kidney Int 2002, 61:599-608

72. Yasuda T, Kondo S, Homma T, Harris RC: Regulation of extracellular matrix by mechanical stress in rat glomerular mesangial cells. J Clin Invest 1996, 98:1991-2000

73. Ingram AJ, Ly H, Thai K, Kang M, Scholey JW: Activation of mesangial cell signaling cascades in response to mechanical strain. Kidney Int 1999, 55:476-485 